\title{
Institutional Change in the Era of Globalization: A Comparison of Corporate Pension Policies in Japan and the U.S.
}

\author{
Ashby H. B. Monk \\ (ashby.monk@ouce.ox.ac.uk)
}

\begin{abstract}
Affiliations. Oxford University Centre for the Environment and Christ Church, University of Oxford

Acknowledgements. Support for this paper was provided, in part, by Pensions \& Investments, Nikko Financial Intelligence, the Oxford University Centre for the Environment and the Lupina Foundation (Toronto). The author would like to thank Susan Christopherson, Gordon L. Clark, Ronald Dore, Martin Hess, Courtney Monk, Jamie Peck, Erica Schoenberger, Neil Wrigley and Dariusz Wójcik for helpful comments on a previous draft. The results and interpretations are the sole responsibility of the author; none of the above should be held to account for any errors, omissions, or opinions expressed herein.
\end{abstract}

Abstract (203 Words). The relationship between globalization and institutional change is an issue frequently debated in economic geography and the social sciences. Some see firms, whatever their national culture or heritage, as facing common market forces that undermine self-determination and predict convergence towards a set of global best practice. Others are sceptical, arguing that different country-specific 'varieties of capitalism' have market distorting effects due to long-established differences in domestic institutions, resulting in path dependence that limits the strength of global incentives to converge at the firm-level. Others still are unconvinced by both these arguments. As such, this paper seeks to advance our understanding of globalization's impact on institutional change by adopting a firm-based perspective that tests whether the Japanese corporate pension experience parallels US corporate pension experiences. This allows for certain path dependence axioms to be tested. This paper finds that American and Japanese pension sponsors, despite clear manifestations of societal differences, have had similar private pension experiences. So, some of the predictions held by path dependence and the varieties of capitalism are not confirmed in this case. However, convergence towards a 'best practice' pension solution is also rejected. As such, the paper concludes that research focusing on the impact of financial markets on institutional change may provide useful insights.

Key Words. Convergence, Path Dependence, Finance, Competitiveness, Pensions 


\section{Institutional Change in the Era of Globalization: A Comparison of Corporate Pension Policies in Japan and the U.S.}

\section{Introduction}

Economic geographers are increasingly interested in the impact of local geographic variation on firms' and institutions' tendencies to converge in the face of global market forces (see Rodrigues-Pose, 1999; Gertler, 2001; Hess, 2004; Peck and Theodore, 2005, 2007; and Clark and Wojcik, 2007). In particular, two questions appear to be at the heart of this research programme: 1) many wonder how local, regional and national geographies (i.e. laws, cultures, norms and histories) respond to global market forces; and 2) many wonder whether filtering global forces through these geographies results in convergent or path-specific developments. While many have come to view the convergence hypothesis as overly simplistic (Hay, 2004), ${ }^{1}$ path dependence has become extremely popular within economic geography (see Gertler, 2001; Hess, 2004; Peck and Theodore, 2007) and the social sciences as a whole (see Hall and Soskice, 2001). This view predicts the existence of multiple market equilibria over time and among places; corporate strategies anchored in these different places (nation-states) will not converge, as firms react to their economic environment according to their specific 'variety of capitalism’.

\footnotetext{
${ }^{1}$ According to Hay (2004, 232), compared with convergence proponents in the "airport lounge/business school globalization literature", the divergence or 'dual-convergence' thesis is "more sophisticated theoretically, altogether more exhaustive empirically, and increasingly influential in contemporary debates...This perspective represents perhaps the most systematic attempt to date to explore, expose and detail the institutional mechanisms involved in process(es) of convergence and divergence.”
} 
In short, path dependence with its roots in economic geography and the varieties of capitalism with its roots in international political economy, are conceptualizations of how firms and institutions respond to globalization. ${ }^{2}$ Each theory shares a core tenet: local factors deflect and minimize global pressures to converge at the institution or firm-level. Given the wide-ranging implications, it is natural for Boyer $(2005,1)$ to ask a simple question: "Is there a single brand of capitalism or can a significant variety of capitalisms coexist even in the long run?”

Martin and Sunley (2006) argue that economic landscapes inevitably take on the legacy of the past, which over time results in economic differentiation. Significantly, this has been linked with different economic outcomes (see Christopherson, 2002, 2007). Moreover, different national economic policies have been tied to variable corporate strategies (see Glasmeier, et al, 1993), while differing social practices have also been associated with variable corporate behaviours (Storper, 1997). As a result, firms are seen to be 'constructed' by their social-institutional environment (Gertler, 2001), rooted in a specific time and place that limits convergence towards global best practice. In short, geographers are sceptical of claims of the inevitability of global convergence (cf Ohmae, 1990), and have thus developed theories that situate firms within volatile but nonetheless path dependent, heterogeneous landscapes.

Nevertheless, while path dependence is a natural fit with economic geography due to its promotion of heterogeneous economic landscapes, new research continues to raise

\footnotetext{
${ }^{2}$ However, the varieties of capitalism takes a much broader view of economic activity than path dependence, focusing on institutions across countries.
} 
questions about its explanatory power. For example, globalization is seen to subject firms to competitive pressures that necessitate strategies characterized by flexible innovation (Schoenberger, 1997); the firm's precarious place and purpose in the era of global capitalism is well documented (Taylor, 1984; and Dicken and Thrift, 1992; Dicken, 1998; and Yeung, 1998). Also, flexibility, which refers to a firm's ability to adjust its inputs for the changing demand of its outputs, is seen to be the touchstone of the post-Fordist era, as firms are searching for corporate geographies that maximize their capacity to respond to global competitive forces (see Zingales, 2000; McCann et al., 2004). As Buckley and Casson (1998, 23) argue, "survival and prosperity in a volatile environment depend upon flexible response.” This is clearly a world where global forces are having profound impacts on firms, which begs the question: will the pursuit of flexibility lead to convergence?

At the very least, the above research raises questions about path dependence and the varieties of capitalism as theories for explaining globalization's impact on institutions. As Peck and Theodore $(2007,750)$ argue, "there are some serious open questions about whether [the varieties of capitalism] is an appropriate way to comprehend economic variegation.” As a result, a separate conceptualization of institutional change known to some as the 'geography of finance' (Clark and Wójcik, 2007)—though it is perhaps more adeptly referred to simply as the 'financial thesis'—warrants deeper exploration. This conceptualization, which takes a more targeted view of institutional change, stands in contrast to both of the above theories: it views all firms and institutions as being subject 
to the pricing mechanism of global finance while making no predictions about convergence towards a best practice (see Clark and Wójcik, 2007).

Given these ongoing conceptual debates, this paper seeks to compare the convergence and path dependence conceptualizations to the new concepts germinating from the financial thesis. Subsequently, having rejected the convergence hypothesis for the specific case under consideration, I then test whether path dependence or the financial thesis has more explanatory power. I do this through a quantitative assessment of corporate and behaviour strategies across different 'varieties of capitalism' (following Soskice, 1990; and Hall and Soskice, 2001). Specifically, I evaluate whether the strategic behaviour of Japanese corporate pension plan sponsors parallels the strategic behaviour of U.S. corporate pension plan sponsors. These countries and firms are selected for three main reasons:

- First, Japan and the United States are the two largest national economies in the world. Moreover, the rise of Japan has been linked with fundamental changes in capitalist systems relative to traditional American norms (see Storper, 1987). Indeed, each country is frequently cited as having different 'varieties of capitalism' (see Kester, 1996; Pauly and Reich, 1997; Kenworthy, 1997; Dore, 2000; Gertler, 2001; and Peck, 2005) and different models of corporate governance (see Jacoby, 2000). As a result, Dore (2000) argues that Japan has the capacity to resist “American-led” global capitalism because of its cultural, racial and historical distinctiveness. 
- Second, private defined benefit (DB) pensions ${ }^{3}$ provide a useful test case with which to examine corporate strategies across countries. Both Japan and the United States have large private DB pension systems. Indeed, according to the Japanese Ministry of Health, Labor and Welfare, there are approximately 40,000 DB pension plans in Japan as of $2007,{ }^{4}$ and roughly 30,000 plans in the United States. ${ }^{5}$ According to Watson Wyatt, in 2006 Japan’s pension fund assets surpassed \$3 trillion, placing it second behind only the United States. ${ }^{6}$ Moreover, DB pension plans have been cited as institutions likely to engender the differentiated corporate strategies predicted by the ‘varieties of capitalism’ (Hall and Soskice, 2001). For example, Dore et al. (1999, 117) ask, "Will the shift in pension systems from publicly regulated fixed obligations to private risk-bearing financial assets proceed further in the Anglo-Saxon economies and become a serious trend in the others?" This is precisely the focus of this paper. ${ }^{7}$

- Finally, while DB pensions are used as the focal point of analysis, these financial institutions are also integrated into all aspects of society. ${ }^{8}$ Indeed, pensions have implications for the firms that sponsor them, but also the state, legal and institutional arrangements, employment systems, finance, social welfare, and much more. As such, pensions represent an ensemble of national economic geographies; they touch on all

\footnotetext{
${ }^{3}$ This is a type of pension that promises beneficiaries a benefit that is a function of years of service and salary. It was extremely popular among manufacturing firms in the mid- $20^{\text {th }}$ century (see Sass, 2006).

${ }^{4}$ Over 38,000 plans are tax qualified pension plans, which are slated for termination and replacement by an alternative pension arrangement by 2012, and roughly 2,000 are the newer DB corporate pensions.

${ }^{5}$ See: http://www.pbgc.gov

${ }^{6}$ See: 2007 Global Pension Assets Study

${ }^{7}$ For a broad discussion of Japan's pension system, see "Social Security Programs throughout the World: Japan, 2006”, a publication by the US Social Security Administration.

${ }^{8}$ Point made by Jamie Peck and Erica Schoenberger in private communication.
} 
aspects of the path dependence and the geography of finance literatures, making them an important and perhaps unique test case.

This paper uses a dataset comprised of expert opinion survey findings. The survey targets 'pension experts' in Japan and the U.S. in order to shed light on the differing private sector pension experiences in each country. While acknowledging that opinion is not the same as experience, this paper argues that when experts are surveyed on issues within their 'domain of expertise', the findings can serve as a suitable proxy for actual but nonexistent evidence. With 1,266 U.S. pension expert responses and 502 Japanese responses, the data provides a unique resource with which to study each country's DB pension experiences. To my knowledge, no other survey explores these issues across these countries.

The paper proceeds as follows. Section two sets up the analytic focus of the paper, illustrating, in general, the impact of private DB pensions on plan sponsors. Section three then grounds the analysis in the broader social sciences literature and explains the polarizing views of global capitalism and convergence. Moreover, the new conceptual insights being developed in the financial thesis are introduced. Next, section four further explains the unique data and methodological approach. Section five then uses the data to elucidate the specificities of Japanese and American pension experiences. Specifically, this section examines whether private pension plan sponsors in these two varieties of capitalism experience different firm level impacts and demonstrate different behaviours. 
In effect, this section evaluates whether the arguments underpinning path dependence or the financial thesis have more explanatory power in this specific case.

I conclude that American and Japanese pension plan sponsors are impacted and respond in similar ways to global pressures with respect to their pension strategies. Indeed, globalization appears to encourage firms in both jurisdictions to close or freeze their DB pensions despite the existence of different laws, cultures, norms, histories and, indeed, varieties of capitalism. As such, this raises questions about path dependence as a tool for understanding globalization's impact on firms and institutions. However, the empirical evidence also rejects the convergence hypothesis, as there is no best practice pension solution currently available to these firms. So, while firms in both jurisdictions may be moving away from DB plans, there is a wide array of institutional replacements. As such, the paper concludes that the financial thesis has important insights for understanding institutional change in the era of globalization (see Clark and Wójcik, 2007); it argues that while different types of economic systems can co-exist in the face of globalization, the pressure of global finance will drive firms integrated into financial markets towards behaviours that maximize firm value on these markets.

\section{Global Competitiveness and Private Pension Systems}

In a DB pension, the plan sponsor (the firm) makes contributions (in the form of financial assets) into a separate trust (the pension plan) to cover promised pension benefits (liabilities) to plan beneficiaries (current, previous, and retired workers). Given that the responsibility to ensure payment of the pension resides with the firm, any exogenous 
force that alters the current and anticipated value of the pension assets or liabilities may result in additional mandated cash contributions. As a result, certain hard to quantify risks have been damaging to plan sponsors (Monk, 2008a). In particular, increasing longevity poses a substantial cost risk, as the population as a whole has been 'aging'. Also, the risk posed by inflation can be serious for those firms that index pension benefits, since it complicates the task of estimating liabilities over the long term. In addition, the vulnerability of the plan sponsor to wage inflation and regulatory changes have also proven significant. According to Clark and Monk (2007), these “unhedgeables” are key variables within a DB pension that leave sponsors exposed to significant plan volatility, risk and cost.

To reinforce this point, take the following example: an employee is promised a pension by her firm that is a function of years of service and final salary (and some percentage discount function). In her first year of retirement at age 65, based on these inputs, she receives a DB pension worth $\$ 35,000$. This pension, which will be indexed for inflation and subject to occasional cost of living adjustments, will be paid until death. However, when the firm agreed to make this pension promise several decades ago, its internal actuarial calculations (which were based on standardized mortality tables) predicted that this worker would live to 72 years old. As a result, the firm made contributions to the pension plan accordingly. However, over the past thirty years, improvements in medicine and nutrition have had dramatic impacts on life expectancy. So, this same employee that the firm anticipated would live for seven years after retirement will now live for 12 years after retirement to 77 . This single miscalculation cost the firm $\$ 175,000$ more than 
anticipated (in present dollars). This simple example exposes the vulnerability of the plan sponsor to the risks and costs of DB pension plans.

Considering the firm-specific vulnerabilities highlighted above, it is significant to note that poor investment policies, inaccurate actuarial predictions, non-transparent accounting, regulatory changes and many more problems have been characteristic of DB pensions (Clark and Monk, 2008; Ambachtsheer, 2007; Clark and Urwin, 2008; and Monk, 2008b). As a result, today's plan sponsors, which have in effect inherited these pension costs and risks from past generations, are faced with difficult choices with respect to corporate strategy. Moreover, the risks inherent to the DB pension combined with the changing nature of globalization make this institution particularly difficult to reconcile with the competitive demands placed on certain firms (Monk, 2008a). Referring specifically to private pensions, Clark and Wrigley (1995, 209-210) argue, "Large sunk costs [such as DB pensions], in the end, threaten the very future of the corporation”.

General Motors’ CEO Rick Wagoner advances this point: he argues DB pensions “put US manufacturers at a severe disadvantage to overseas competition...the cumulative effect of many well-intentioned policies that now harm American manufacturing and our nation's ability to compete effectively in the global market place". ${ }^{9}$ In 2003, GM contributed $\$ 18.5$ billion to its US pension plans. ${ }^{10}$ While blaming pension costs for the entirety of GM's problems may be overly simplistic due to the complex dynamic nature of competitiveness, these costs have undoubtedly been a problematic burden for the firm.

\footnotetext{
${ }^{9}$ Remarks to Economic Club of Chicago on February 10, 2005.

${ }^{10}$ GM Annual Report: 2003. Management Discussion and Analysis of Financial Conditions and Results of Operations. Financing Structure.
} 
Additional pension costs associated with the unforeseen factors cited above compound other problems by siphoning off much needed capital that could otherwise be reinvested in the business. According to John Engler, CEO of the National Association of Manufacturers, "these external costs reduce profitability and tie up dollars that would otherwise be spent on investment, research and development, and new product lines”. ${ }^{11}$ As Monk (2008a, 212) argues, by diverting this capital, “a downward cycle takes hold that can affect all facets of the organization and threaten the very future of the firm." Clearly, DB pensions come with a high cost, and in many cases they are a competitive constraint for the firms that sponsor them.

The above begs the question: are these corporate woes isolated with Anglo-American firms or is it instead a global phenomenon? While the majority of DB pension research has been focused on the plight of Anglo-American plan sponsors, firms in Japan face similar competitive problems associated with their DB pensions (Clark and Mitchell, 2002). Huh and McLellan (2006, 34) find in Japan a "tension between preserving the current pension system and preserving...the competitiveness of companies...” Indeed, Japanese firms' commitment to traditional lifetime employment contracts has waned in the face of international competition (Seike, 1997). According to Charles Ruffel (cited in Clark and Mitchell, 2002, 27), “For all the talk about Japan’s societal need for defined benefit plans, an exodus of Japanese corporations fleeing debilitating defined benefit framework for less onerous defined contribution systems can be taken as a given.” Such a statement could easily refer to the U.S. as much to Japan; these two distinctly different

\footnotetext{
${ }^{11}$ See John Engler’s ‘Foreword’ in Leonard, 2006.
} 
countries in terms of culture, histories and national economic policies appear to be facing similar problems associated with private DB pension provision.

Indeed, Huh and McLellan (2006) show that employer pension plan closures in Japan rose dramatically over the past decade. Between 1974 and 1995, DB pension fund closures took place on average only once or twice per year. However, starting in 1995 this ramped up, peaking in 2003 with 92 pension fund terminations. This trend has also been seen in the United States: the number of private-sector DB plans peaked at 112,000 in the mid-1980s; the number of plans is now 30,000. ${ }^{12}$ Both countries have thus faced a dramatic increase in DB pension terminations. As a result, both have in recent years implemented overhauls of their pension regulation with the hope of returning their respective systems to firmer footing (see Monk, 2008a and Usuki, 2007). As important social welfare providing institutions that are also considered to be competitive constraints, Japanese and U.S. DB pensions are ideal cases for engaging in the theoretical and empirical debates revolving globalization and institutional change.

\section{Globalization and Institutional Change}

The forces at work in globalization are extremely complex. As such, conceptualizing their relationship with institutional change has proven to be a difficult task. As is demonstrated below, the mainstream theories view this relationship in bi-polar terms, such as 'convergence' or 'path dependence' (see Christopherson, 2002; Hay, 2004). ${ }^{13}$

\footnotetext{
${ }^{12}$ See: www.pbgc.gov

${ }^{13}$ The focus academics have on these two concepts perhaps reflects the high stakes involved with this debate: on the one hand, if theories espousing global convergence are correct, then certain non-competitive institutions will be dismantled to make way for more competitive economic environments. On the other
} 
Below, the main tenets of these theories are presented. This facilitates the detailed introduction of the financial thesis, laying the foundation for the empirical analysis to follow.

Convergence: As Gertler $(2001,7)$ says, “convergence may be said to occur when firms originating in different national institutional spaces implement the same production methods or practices." According to this view, firms and countries, whatever their culture or institutions, are seen to be facing common global market forces that necessitate analogous competitive responses. In the long-term, this undermines local autonomy and self-determination, foreshadowing private and public institutional convergence towards a set of global best practices (see Ohmae, 1990). Global capitalism is thus seen as a homogenous force that constrains local autonomy over institutions and practices. Peck and Theodore (2007, 731) describe this as, "One world, one best way, no alternatives." While Peck and Theodore may be using hyperbole, a more nuanced version of convergence does have some purchase throughout the social sciences.

Coe et al. $(2004,475)$ explain: “The more a region is articulated into global production networks, the more likely it is able to reap the benefits of economies of scale and scope in these networks, but the less likely it is able to control its own fate.” Deeg and Luts (2000) further elucidate this point, arguing that integration of markets constrains the decision making of firms and governments, creating minimum requirements to achieve competitiveness. Clearly, for those that do not meet this minimum requirement, some sort

hand, if theories promoting path dependence and the varieties of capitalism are confirmed, many of these important social institutions may be sustained over the long-term without damaging corporate or national competitiveness. 
of convergence could be expected. So, while economic integration comes with considerable economic benefit, it may also limit local authority over policies, suggesting convergence towards certain fundamental, global principles of competitiveness. As Thatcher (2004) shows, international economic forces can have significant and similar impacts on countries despite differing varieties of capitalism. Some view the inevitable outcome as a race to the bottom in the provision of uncompetitive social welfare services (Greider, 1997).

Path-Dependence: The counter-weight to this view is embodied in the path dependence or varieties of capitalism conceptualizations. These take economic, cultural, political and historical geography as crucial insulators from (or at least intermediaries that buffer) global competitive pressures that otherwise might force convergence. Indeed, many question global capitalism as a homogenous phenomenon (see Allen and Gale, 2000; and Hall and Soskice, 2001) and are thus sceptical about institutional convergence between countries (see Ferrera, et al., 2001; and Krugman and Baldwin, 2002). Country-specific varieties of capitalism are seen to have market distorting effects due to long-established differences in domestic institutions. This embedding or path dependence limits the impact of global incentives for convergence (see Boyer and Drache, 1996).

As Pauly and Reich (1997, 3) argue, "The institutional and ideological legacies of distinctive national histories continue significantly to shape the core operations of multinational firms based in Germany, Japan, and the United States.” Indeed, these "histories" filter and alter the competitive pressures from the global to the local level, 
thus resulting in different corporate responses to similar global pressures. Indeed, Hall and Soskice (2001) predict that national differences will have tangible outcomes in terms of varying corporate impacts and responses stemming from globalization. Albert (1993) and Dore et al (1999) argue that Japan and the United States represent Rhinish and Anglo-Saxon varieties of capitalism (see also Gertler, 2001). As a result, in contrast to the above view, path dependence and the varieties of capitalism approaches hold that inherited institutions are sustainable in certain contexts due to historical specificities, even in the face of global market competition.

Financial Thesis. The financial thesis offers a targeted conceptualization of institutional change that-despite its restrictive focus on a certain subset of economic actors and institutions integrated into financial markets—straddles the convergence and path dependence camps by integrating components of both into a new conceptual model. Indeed, it sees the world through the lens of financial markets and actors and posits that these markets and actors price institutions and structures whatever their geography and history (Clark and Wójcik, 2007). To the extent that a firm, be it in Japan or the United States, relies on financial markets for capital, its institutional and organizational idiosyncrasies will be priced (i.e. discounted) by the global financial market. This pricing mechanism creates incentives that challenge established corporate and institutional characteristics.

As Blackburn (2002) argues, flows of money around the world are challenging inherited institutions and customary practices. This price may be low and thus deemed worth 
paying depending on the jurisdiction's specific geographies. Or, this price may be high, leading to a transition away from a particular costly institution in jurisdictions around the world. Characteristics that constrain competitiveness will come with a higher cost in financial markets than characteristics that spur competitiveness, and sustainability is a function of this cost.

Bauer et al $(2007,2)$ show that large European companies are moving towards shareholder-friendly practices that are consistent with the demands of global financial markets: "Whatever the formal design and structure of a country's model of corporate governance, portfolio investors are able to exert pressure on the managers of large firms to act in ways consistent with shareholder value rather than stakeholder value (short-term rather than long-term value).” Indeed, global finance has been shown to have clear consequences for corporate behaviour and governance (see Gilson, 2000 and Christopherson, 2002). In short, the financial thesis argues that how a firm is financed will have implications for how it is managed (see O’Sullivan, 2003).

Yeung $(2000,401)$ gives credence to this view: “Today, many Asian business firms face the dilemma of succumbing to the pressures of transparency in order to secure global finance while preserving their traditional practices of network reliance and intricate family ownership and / or control...for those Asian firms and/or countries in search of financial resources from outside their home countries and/or regions, it is important to secure the consent and recognition of global financiers for good governance and return to investments. These global financiers are leading bankers, fund managers and brokers.” 
Also, Lane (2003, 86-87) demonstrates the impact of financial markets on German firms: "The first source of change has been the liberalization of international capital markets and the greater readiness of hitherto 'national' capital to seek the most profitable opportunities for both accessing and investing capital wherever this may be in the world.” As such, while taking local geography seriously, the financial thesis recognizes the impact of global forces on firms that have integrated onto global financial markets.

Significantly for the discussion in this paper, institutional investors have been shown to influence the internal practices of American and Japanese firms despite their different varieties of capitalism (see Suto and Toshino, 2005; and Altunbas et al, 2007; Jacoby, 2007). First, Gilson (2000) shows that Japan "piggybacks" on certain portions of the US financial system, such as venture capital, requiring Japanese corporate practices to shift towards U.S. practices in order to gain access to this capital. Moreover, the growing importance of foreign shareholders (and also the development of the market for corporate control) in Japan has had profound impacts on corporate practices in recent years (Altunbas et al., 2007). As Jacoby (2000, 15) notes, "Financial deregulation and the growth of foreign ownership are forcing Japanese managers to pay greater attention to shareholders and have induced voluntary changes...” (a point furthered by Schulz, 2004). As a result, according to Dore (2007), Japanese corporate managers are today primarily concerned with their stock price as a measure of performance. Consequently, global finance is having dramatic impacts on Japanese industry; Dore refers to this as a shift from 'industrial relations' to 'investor relations'. For example, Japan's Stock Analyst's 
Association, which had only 1,000 members in 1981, now has roughly 21,000 members (Dore, 2007).

So, global forces are a clear component of the financial thesis. However, the local is equally important in this conceptualization: it makes no predictions about what firms and nations will converge on. In other words, this is not a conceptual tool that predicts convergence towards a best practice. It simply notes that firms will need to pay a price (in terms of valuations on financial markets) to sustain certain institutional characteristics. The local response engendered by this global pressure is not seen to be a race to the bottom in terms of social welfare provision; it is, in severe cases, a race from the bottom in terms of financial value. Moreover, as is shown below, while the financial thesis may predict that certain institutions are unsustainable, thereby creating similar gaps within firms across jurisdictions, what fills this gap in terms of institutional replacement will be highly differentiated and based on local factors. In short, local geographies will continue to have sway over the behaviour of local firms and institutions, but certain global forces cannot be ignored.

\section{Data Methodology}

Based upon the above discussion, this paper seeks to determine quantitatively which of the above theories has more explanatory power in the specific case under consideration; namely, globalization's impact on Japanese and American DB pension plan sponsors. Specifically, this paper evaluates whether path dependence or the financial thesis has more explanatory power in this case-previous research having already rejected the 
convergence hypothesis in the case of private sector pension policies (see Whiteford and Whitehouse, 2006). This is done using the findings of a proprietary survey of expert opinion across both countries. This specific survey has been conceptualized, developed and implemented over the course of 18 months. To my knowledge, no other survey explores these issues across these countries, making this a unique and interesting dataset.

With the support of the British Academy, the Lupina Foundation, and colleagues at Harvard University and the University of Toronto, a "DB pension liability summit” was convened in May 2006 at Oxford University to consider the prospects for private DB pensions. ${ }^{14}$ So as to gauge the level of agreement and disagreement on the crucial issues exposed in this conference, attendees were asked to respond to a 27-statement survey with the results compiled and then distributed after the event. Respondents were presented with a statement and then given five response choices: "strongly agree", “agree”, “neutral”, “disagree”, “strongly disagree”. ${ }^{15}$

In designing this survey, a number of issues were considered. First, it was crucial that the topics raised be relevant to the history of DB pensions in a variety of settings. At the same time, it was clear that it should not be so general in reach that it produced superficial conclusions of little relevance to any particular country. Second, the pilot survey illustrated the need to take into consideration political and cultural sensitivities

\footnotetext{
${ }^{14}$ For details and a summary of proceedings for this conference see: http://www.ouce.ox.ac.uk/news/phclcs/

${ }^{15}$ I acknowledge that the "binary" tone (agree/disagree) of these results may hide the complexity of some of the issues under consideration. In order to control for this, respondents were given the option of marking 'neutral', which was seen to be an alternative for those unwilling to be restricted to the agree or disagree categories.
} 
with respect to the provision of DB pension plans across jurisdictions. Indeed, certain phrases were viewed as inflammatory in one jurisdiction (even if they were viewed as commonly accepted in another). As a result, considerable effort went into writing simple questions that engaged, rather than challenged, pension experts from around the world, while still eliciting interesting results. Third, it was important that respondents' opinions be tested for coherence and consistency; there were thus overlapping and related questions included in the survey intended to gauge consistency of responses. Fourth, it was important that the survey allow for the assessment of opinions against core academic assumptions, such as convergence, path dependence and the geography of finance. Finally, it was crucial that respondents in both countries understand and internalize the specific meaning of each question. As such, significant effort went into translating the questions: multiple, independent Japanese language translators with specific expertise in finance and pensions were utilized to ensure that the integrity of the questions was upheld in the translation.

After the pilot survey, a larger survey was launched in early January 2007 as an online instrument with the support of Pensions \& Investments and academic institutes and experts from around the world. ${ }^{16}$ Our partners facilitated delivery of this survey to pension experts. After an “open-window" of about 4 weeks (beginning January $7^{\text {th }}$, 2007), the data were collated into a composite file for analysis. Of the nearly 1600 responses, roughly 1300 were from the United States (of which 1266 were complete).

\footnotetext{
${ }^{16}$ The survey received support and assistance from the Centre for Pensions and Superannuation, the Center for Retirement Research at Boston College, KPA Advisory Services, the Lupina Foundation (Toronto), the Pension Research Council, the Retirement Security Project, the Transport Studies Fund at Oxford, and Watson Wyatt.
} 
Roughly one third of these respondents were from pension fund service providers (e.g. pension actuaries, consultants, lawyers, money mangers and so on), one third were corporate pension fund representatives, one sixth were public pension fund representatives and the remainder came from government, academia and union pension plans. The respondents had a weighted average pension related work experience of roughly 15 years. Subsequent to this survey, and its success, a Japanese version was also completed in May 2007 with help from Nikko Financial Intelligence. This produced 502 expert responses. Roughly one half of these respondents were corporate pension representatives, one third were pension fund actuaries, and the remainder came from other pension services, academia, or government. Again, the respondents had a weighted average pension related work experience of roughly 15 years. These two surveys provide the quantitative data for this paper. For further explanations of the sampling frame and survey collection see Clark and Monk (2008).

This type of survey requires certain methodological and logistical clarifications. First, in terms of logistics, since this was an online survey, it required specific tools to ensure its credibility. It was launched with a format designed to disrupt routine "form-filling”. This was accomplished in a number of ways including ensuring that the order of questions did not automatically cue responses from one question to the next. As well, the actual format of the survey included dis-junctures between questions that forced some respondents to work-through the sequence of options. And finally, the survey was presented as a timelimited window of opportunity, encouraging respondents through electronic prompting to quickly take advantage of the opportunity to register their views. Being an online 
instrument, as respondents finished the survey, the results were automatically compiled and sent to a central electronic collection point.

Second, in terms of methodology, while opinions are not equivalent to fact (Useem, 1995), these types of expert opinion surveys are important tools within social science research. For example, according to Castles and Mair (1984), in situations where reliable and objective data is missing, 'expert' opinion or judgments can act as a reliable substitute. In this case, there are no firm-level surveys of DB pension plan sponsors in both Japan and the United States, suggesting that this is an opportune situation for an expert opinion survey. Nevertheless, the reliability of these surveys depends on the characteristics of the respondents; surveys of highly educated individuals will typically be more reliable than surveys of the mass public for a given domain (Alwin and Krosnick, 1999; and Weber, et al., 2002). This implies that being an expert on a subject makes one's responses on this subject more reliable (Huber and Inglehart, 1995). So, as Dorn and Huberman (2005) suggest, experts' responses can be proxies for actual evidence when they are surveyed in the specific domains for which they are highly knowledgeable. By virtue of their education, profession, and experience, the pension 'experts' surveyed here arguably have this kind of special knowledge, beyond that of the average person. This is sufficient enough that I may rely upon their opinion as a proxy for actual evidence. Moreover, by cross checking the expert accounts and triangulating these findings with other qualitative and empirical findings, the results do convey rigor (Strauss and Corbin, 1998). Indeed, this paper integrates qualitative with rigorous quantitative methodologies (see Sheppard, 2001). 


\section{Survey Results: Japanese and U.S Pensions}

This section tests whether DB pensions have similar institutional characteristics despite being rooted in American and Japanese 'varieties of capitalism'. Subsequently, this section tests to see how firms are affected by this institution when faced with global competitive pressures. The goal is to evaluate whether the experience in these two countries conforms to the predictions made by path dependence or those proffered by the financial thesis. This is done in two ways: 1) through a charting and analysis of the data; and 2) through statistical tests, such as a chi-square test of significance, that evaluate the degree to which Japanese and American experts are in agreement/disagreement on a certain statement. ${ }^{17}$

Institutional Agreement. As we begin this analysis, it is important to establish institutional similarities between the two jurisdictions. This is done so we may confidently make comparisons between the Japanese and U.S. experiences.

First, at the most basic level, experts in both countries overwhelmingly agree that DB pension deals are long-term contractual remuneration agreements for employees' services and/or support (see Chart 1). While the statistical testing shows that the magnitude of the agreement does vary by country (chi-square is 12.0148 and p-value is 0.001 ), this still suggests that the status of the DB pension plan within the private sector is highly similar between these two countries. Further agreement was uncovered in responses to the

\footnotetext{
${ }^{17}$ The analysis aggregates the "agree” and "strongly agree” response categories, the "disagree” and "strongly disagree" response categories and ignores the "neutral” category (see Table 1 for details).
} 
following statement: "The most forceful advocates for DB pensions are older workers nearing retirement” (see Chart 2). In fact, the statistical testing for this confirms that the two countries agree to the same level (chi-square is 1.9938 and P-value is 0.158 ). This shows that DB's proponents in both countries are older workers nearing retirement.

Next, the survey sought to evaluate, in general terms, whether both countries had faced similar levels of regulatory oversight. Indeed, in the U.S., Monk (2008a) demonstrated that regulatory intervention had changed the very nature of the pension deal, making concrete what had intentionally been set up as a contingent promise. In addition, Usuki (2007) has shown that private DB pension regulation has changed dramatically in Japan since 2001. As such, the experts in both countries were presented with the following statement: “The DB pension was originally an implicit 'promise' that was changed by regulatory intervention into an explicit contractual 'guarantee'.” Remarkably, both sets of experts expressed overall agreement with this statement (see Chart 3). In the US, experts agreed at a rate of $45 \%$ and disagreed at a rate of $30 \%$. In Japan, the experts agreed at a rate of $54 \%$ and disagreed at a rate of $27 \%$. Statistical testing also shows high levels of agreement, but not enough to "accept" equality (Table 1). So, in this case, both Japanese and American experts did agree, but the magnitude of agreement was different. In any case, this implies that the 'pension deals' in both countries have undergone similar changes as a result of governmental reforms.

Building on this point, we sought to establish whether this regulation (and governance) was viewed by experts in both countries as burdensome. As such, the experts were 
presented with the following: "I would characterize DB regulations and governance as becoming overly restrictive.” Experts in Japan and the United States both agreed on average with this statement, further reinforcing the similarities between the institutional environments (see Chart 4), but the level of agreement was slightly different statistically.

Finally, we sought to evaluate whether the experts viewed the DB liability as escalating over time. As such, we presented them with: "DB pensions were built incrementally over the course of 50 years; the escalation of commitments resulted in a large unexpected burden for sponsoring firms.” Remarkably again, both sets of experts, at the margin, agreed, but the Japanese experts were more likely to agree with this statement than the Americans (see Chart 5).

Consequently, we are confronted with perceived institutional similarities across these two jurisdictions. In short, Japanese and US DB pensions, according to these expert respondents, share many similarities despite clear differences in local geographies. As such, we can confidently proceed with this analysis: these are similar institutions embedded in different varieties of capitalism.

Impacts. Building on the above institutional analysis, this section seeks to determine how DB pensions impact firms in the two jurisdictions. Indeed, the logic underpinning path dependence and the 'varieties of capitalism' would predict that, despite certain institutional similarities cited above, the geographic differences between Japan and the U.S. should filter the global pressures and result in idiosyncratic corporate behaviour. 
However, the financial thesis would predict that due to the high costs associated with sponsoring a DB pension plan (see section 2), firms in both countries would view them as competitive constraints (and move away en masse due to their discounting on global financial markets). The below will reveal which conceptualization has more explanatory power.

First, we presented the experts with a general statement: "Any organizational component that hinders a firm's flexibility with respect to resource allocation and production decisions would put the firm at a disadvantage.” As indicated earlier, the varieties of capitalism suggests that Japanese firms would be less concerned with flexibility than their U.S. counterparts, due to their location in a 'coordinated market economy'. However, experts in both countries overwhelmingly agreed with this statement (see Chart 6 and Table 1), suggesting that both American and Japanese firms are in fact conscious of their need to be flexible when faced with global market forces. This is a finding predicted by the financial thesis.

Subsequently, we evaluated whether the experts viewed DB plan sponsors as being capable of managing the risks associated with a DB plan. As argued earlier, these risks are considerable, so the experts were presented with the following statement: "Plan sponsors cannot take into consideration all unforeseen contingencies stemming from long-term DB risks.” Once again, the experts from both countries overwhelmingly agreed (see Chart 7), even if the magnitude of this agreement varied (Table 1). So, both 
countries acknowledge that plan sponsors, as a whole, are having considerable difficulty managing their DB pension risks, in Japan as in the United States.

Next, we sought to evaluate how DB pension plan sponsors in both countries were responding to global competitive pressures. As such, we presented the experts with the following: "Increased market competition stemming from deregulation and globalization has weakened the competitive position of private DB plan sponsors with large pension liabilities.” 55\% of Japanese agree, while 29\% disagree, and 69\% of Americans agree, while $17 \%$ disagree. To be sure, the magnitude of agreement varies between the two groups (see Chart 8 and Table 1), but the trend remains the same. In both countries, according to the data, the statement appears to be viewed as true by a majority of the respondents. Once again, this is a finding that fits with the predictions made by the financial thesis, as the DB plans are seen to be competitive constraints in both markets.

The above point about competitiveness was further confirmed when the experts were presented with the following: "The embedded nature of the DB pension system presents significant resistance to restructuring." Once again, the experts in both countries overwhelmingly agreed (see Chart 9), which was strongly confirmed by the statistical testing (Table 1). Moreover, this finding suggests that both Japanese and U.S. experts view DB pensions as restrictive legacy liabilities (see Monk, 2008a)

Next, the experts were asked to indicate the main factors driving DB plan sponsors to close and freeze their plans. Significantly, experts in both jurisdictions indicated that 
"increasing costs" were the most burdensome factor for plan sponsors, driving them to close or freeze their plans. So, plan sponsors in both countries view the cost of DB pensions as being too high, which is to a large degree why they are terminating their plans. Once again, this is a finding that corresponds with the claims being made by the financial thesis.

Next, the experts were also asked to evaluate the following: "Asset allocation policy is difficult to determine in DB plans because of the competing trustees' interest in benefit security and plan sponsors' interest in cost containment." On this issue, which should inspire a negative response for well governed pension plans, the experts' registered a remarkably high level of agreement, (see Chart 10). Moreover, the statistical test shows that both nationalities agree equally (chi-square is 0.0036 and the p-value is 0.952 ). Clearly, both countries' private DB pensions are grappling with the same issues, which makes a path dependent outcome unlikely.

Finally, we wanted to move away from firm impacts and evaluate briefly the community level impacts. As such, the experts were presented with the following statement: "Intergenerational deals, of the type made by firms agreeing to pay DB pensions, generate unknown and often negative effects for future generations who are expected to manage the burden of the liability (legacy)." In this case, once again, experts in both countries were in agreement (see Chart 11). According to the statistical test, we can weakly conclude that both sets of experts agree to the same level (see Table 1). As such, 
it appears that DB pensions are perceived by both sets of experts to impact future generations in a similarly negative way.

The agreement between American and Japanese experts across a range of specific pension related issues is remarkable. Significantly, the predictions made by path dependence and 'varieties of capitalism' about local geographies filtering or altering economic forces did not materialize. As such, the financial thesis appears to be better at explaining the empirical reality facing firms who sponsor DB pension plans.

\section{Implications and Conclusions}

This paper tests how American and Japanese DB pension plan sponsors are responding to globalization. In short, it seeks to answer and add theoretical context to Dore et al's (1999, 117) question, "Will the shift in pension systems from publicly regulated fixed obligations to private risk-bearing financial assets proceed further in the Anglo-Saxon economies and become a serious trend in the others?”

I find that DB pensions are competitive constraints for firms in both Japan and the United States. This provides some context for the general trend away from private sector DB pension provision, as plan terminations in both jurisdictions have increased dramatically over the past two decades. These findings suggest that Japanese plan sponsors are subject to the same global forces as American plan sponsors. For example, the top reason why plan sponsors close or freeze plans in Japan and the U.S. is the same, increasing costs. So, the view that corporate impacts and strategies would be altered by national characteristics 
was not confirmed. Indeed, the cost of sponsoring a DB pension is too high in Japan as in the U.S. As such, a path dependent outcome appears unlikely in this case. As Peck (1996) adeptly notes, it appears to be very difficult to predict firm behaviour from national identity alone.

Nevertheless, as suggested above, DB pensions' declining popularity among firms in both jurisdictions does not represent a convergence towards any 'best practice' corporate strategy. The similar corporate impacts and behaviours with respect to DB pensions do not imply a race to the bottom in pension provision. Rather, it implies a race from the bottom in terms of financial value and a race to something else. Gertler (2001) shows that 'best practice’ is not easily disseminated, understood or adopted across jurisdictions. So, different types of economic systems can co-exist in the face of a singular global financial force. Indeed, throughout the world, firms and countries are adopting vastly different trajectories with respect to pension provision (see Whiteford and Whitehouse, 2006; Clark and Monk, 2007), even if DB sponsors are moving away from traditional DB plans. For example, the Netherlands has modified their DB system to share the costs more equitably, necessitating enormous institutional innovation. In the U.S., firms are adopting a wide variety of responses, shifting to hybrid DB or even defined contribution (DC) pensions. In the U.K., plan sponsors are closing their DB plans and in some cases not replacing them with anything. In Japan, new DB, Cash Balance and DC plans are being developed. 
So, in the case of private DB pensions in Japan and the U.S., neither convergence nor path dependence adequately explains the empirical reality. The outcomes predicted by the financial thesis are confirmed: DB pensions, independent of jurisdiction, come with too high a cost for firms. The price associated with these funds is too high for any firms to ignore: recall from the data that both American and Japanese experts viewed globalization as weakening the competitive position of DB pension plan sponsors with large liabilities. Also, the high cost of pensions was cited by both sets of experts as being a primary concern, driving sponsors to close or freeze their plans. Clearly, both sets of experts acknowledge the behind the scenes market imperatives driving managerial behaviour; this is, in part, global finance. As such, while the financial thesis makes no claims to be an all encompassing theory of institutional change, as a conceptual tool for understanding the outcomes for firms and institutions integrated into financial markets it does have considerable explanatory power.

In sum, the financial thesis seeks to explain institutional change through the lens of global finance. Specifically, it argues that global financial institutions, which must invest in such a way that maximizes their beneficiaries' welfare, discount non-competitive corporate characteristics and institutions on global markets. The more firms are integrated into financial markets, the more power that these financial institutions will have over their internal authority. As was demonstrated above, these institutions do have increasing power throughout the world, including Japan. Nevertheless, the financial thesis does not dictate how firms or even economies need respond to market forces. So, maximizing firm value in Japan and the U.S. may demand a general transition away from DB pension 
provision, but what replaces DB pensions in these countries will depend on local geographic characteristics. 


\section{REFERENCES:}

Albert, M. (1993). Capitalism Against Capitalism. London, Whurr.

Allen, F. and D. Gale (2000). Comparing financial systems. Cambridge, Mass. ; London, MIT Press.

Altunbas, Y., A. Kara, et al. (2007). "Corporate Governance and Corporate Ownership: The Investment Behaviour of Japanese Institutional Investors." Banco de Espana Documnetos Ocasionales 0703.

Alwin, D. F. and J. A. Krosnick (1991). "The Reliability of Survey Attitude Measurement - the Influence of Question and Respondent Attributes." Sociological Methods \& Research 20(1): 139-181.

Ambachtsheer, K. (2007). Pension Revolution: A Solution to the Pensions Crisis Toronto, Wiley Finance.

Bauer, R., R. Braun, et al. (2007). "The Emerging Market for European Corporate Governance: The Implications for Corporate Capital Expenditures, 1997-2005." OUCE Working Papers in Employment, Work and Finance 07(13).

Blackburn, R. (2002). Banking on death : or, investing in life: the history and future of pensions. London, Verso.

Boyer, R. (2005). "Coherence, diversity and evolution of capitalisms: the institutional complementarities hypothesis, mimeo, CEPREMAP-CNRS-EHESS, Paris."

Boyer, R. and D. Drache (1996). States against markets : the limits of globalization. London, Routledge.

Buckley, P. J. and M. C. Casson (1998). "Models of the multinational enterprise." Journal of International Business Studies 29(1): 21-44.

Castles, F. G. and P. Mair (1984). "Left Right Political Scales - Some Expert Judgments." European Journal of Political Research 12(1): 73-88.

Christopherson, S. (2002). "Why do national labor market practices continue to diverge in the global economy? The "missing link" of investment rules." Economic Geography 78(1): 1-20.

Christopherson, S. (2007). "Barriers to 'US style' lean retailing: the case of Wal-Mart's failure in Germany." Journal of Economic Geography 7(4): 451-469.

Clark, G. L. and A. H. B. Monk (2007). "The 'crisis' in defined benefit corporate pension liabilities Part 1: Scope of the problem." Pensions: An International Journal 12(1): 43-54.

Clark, G. L. and A. H. B. Monk (2008). "Conceptualizing the defined benefit pension promise: implications from a survey of expert opinion." Benefits Quarterly 24(1): 7-18.

Clark, G. L., A. H. Munnell, et al. (2006). Oxford handbook of pensions and retirement income. Oxford, Oxford University Press.

Clark, G. L. and R. Urwin (2008). "Best-Practice Investment Management: Lessons for Asset owners from the Oxford-Watson Wyatt Project on Governance." Journal of Asset Management Forthcoming.

Clark, G. L. and D. Wojcik (2007). The Geography of Finance: Corporate Governance in a Global Marketplace. Oxford, Oxford University Press.

Clark, G. L. and N. Wrigley (1995). "Sunk costs: a framework for economic geography." Transactions of the Institute of British Geographers 20: 204-223. 
Clark, R. L. and O. S. Mitchell (2002). "Strengthening Employment-Based Pensions in Japan." NBER Working Paper Series 8891.

Coe, N. M., M. Hess, et al. (2004). "'Globalizing' regional development: a global production networks perspective." Transactions of the Institute of British Geographers 29(4): 468-484.

Deeg, R. and S. Lutz (2000). "Internationalization and financial federalism - The United States and Germany at the crossroads?" Comparative Political Studies 33(3): 374405.

Dicken, P. (1998). Global shift : transforming the world economy. London, Paul Chapman.

Dicken, P. and N. Thrift (1992). "The Organization of Production and the Production of Organization - Why Business Enterprises Matter in the Study of Geographical Industrialization." Transactions of the Institute of British Geographers 17(3): 279291.

Dore, R., W. Lazonick, et al. (1999). "Varieties of capitalism in the twentieth century." Oxford Review of Economic Policy 15(4): 102-120.

Dore, R. P. (2000). Stock market capitalism: welfare capitalism : Japan and Germany versus the Anglo-Saxons. Oxford, Oxford University Press.

Dore, R. P. (2007). Inevitability. L'economia e la politica: Saggi in onore di Michele Salvati. G. Dosi and M. C. Marcuzzo. Bologna, Mulino.

Dorn, D. and G. Huberman (2005). "Talk and Action: What Individual Investors Say and What They Do." Review of Finance 9: 437-481.

Ferrera, M., A. Hemerijck, et al. (2001). "The Future of the European "Social Model" in the Global Economy." Journal of Comparative Policy Analysis: Research and Practice 3: 163-190.

Gertler, M. (2001). "Best Practice? Geography, learning and the intitutional limits to strong convergence." Journal of Economic Geography 1: 5-26.

Gilson, R. J. (2000). "Globalizating Corporate Form: Convergence of Form or Function." Columbia Law School Working Paper Series 174.

Glasmeier, A., J. W. Thompson, et al. (1993). "The Geography of Trade-Policy - Trade Regimes and Location Decisions in the Textile and Apparel Complex." Transactions of the Institute of British Geographers 18(1): 19-35.

Greider, W. (1997). One world, ready or not : the manic logic of global capitalism. London, Allen Lane.

Hall, P. A. and D. W. Soskice (2001). An introduction to varieties of capitalism. Varieties of capitalism : the institutional foundations of comparative advantage. P. A. Hall and D. W. Soskice. Oxford, Oxford University Press: xvi, 540.

Hay, C. (2004). "Common trajectories, variable paces, divergent outcomes? Models of European capitalism under conditions of complex economic interdependence." Review of International Political Economy 11(2): 231-262.

Hess, M. (2004). "'Spatial' relationships? Towards a reconceptualization of embeddedness." Progress in Human Geography 28(2): 165-186.

Huber, J. and R. Inglehart (1995). "Expert Interpretations of Party Space and Party Locations in 42 Societies." Party Politics 1(1): 73-111.

Huh, E. and S. McLellan (2006). "The tale of two pension reforms: A US-Japan comparison." Pensions 12(1): 33-42. 
Jacoby, S. M. (2000). "Corporate governance in comparative perspective: prospects for convergence." Comparative Labor Law and Policy Journal 22: 5-22.

Jacoby, S. M. (2007). "Convergence by design: The case of CalPERS in Japan." American Journal of Comparative Law 55(2): 239-293.

Kester, W. C. (1996). American and Japanese Corporate Governance: Convergence to Best Practice? National Diversity and Global Capitalism. S. Berger and R. Dore. London, Cornell University Press.

Kenworthy, L. (1997). "Globalization and Economic Convergence." Competition \& Change 2(1): 1-64.

Krugman, P. and R. Baldwin (2002). "Agglomeration, Integration and Tax Harminization." NBER Working Paper Series Working Paper 9290.

Lane, C. (2003). "Changes in Corporate Governance of German Corporations: Convergence to the Anglo-American Model?" Competition \& Change 7(2-3): 79100.

Leonard, J. A. (2006). The Escalating Cost Crisis: An Update on Structural Coset Pressures Facing U.S. Manufacurers. Washington, DC, Prepared for The Manufacturing Institute of the National Association of Manufacturers.

Martin, R. and P. Sunley (2006). "Path dependence and regional economic evolution." Journal of Economic Geography 6(4): 395-437.

McCann, L., J. Hassard, et al. (2004). "Middle Managers, the New Organizational Ideology and Corporate Restructuring: Comparing Japanese and Anglo-American Management Systems." Competition \& Change 8(1): 27-44.

Monk, A. H. B. (2008a). "Knot of Contracts: The Corporate Geography of Legacy Costs." Economic Geography 84(02).

Monk, A. H. B. (2008b). "The Geography of Pension Liabilities and Fund Governance in the United States." Environment \& Planning A Forthcoming.

Ohmae, K. (1990). The borderless world : power and strategy in the interlinked economy. London, Collins.

O'Sullivan, M. (2003). "The political economy of comparative corporate governance." Review of International Political Economy 10(1): 23-72.

Pauly, L. W. and S. Reich (1997). "National structures and multinational corporate behavior: Enduring differences in the age of globalization." International Organization 51(1): 1-\&.

Peck, J. (1996). Work-place : the social regulation of labor markets. New York ; London, Guilford Press.

Peck, J. (2005). "Economic sociologies in space." Economic Geography 81(2): 129-175.

Peck, J. and N. Theodore (2005). Comparing capitalisms: theorizing the presistence of institutional variation. Paper prepare for second DEMOLOGOS meeting, Vienna, June 16-18.

Peck, J. and N. Theodore (2007). "Variegated capitalism." Progress in Human Geography 31(6).

Rodriguez-Pose, A. (1999). "Convergence or Divergence? Types of Regional Responses to Soci-Economic Change in Western Europe." Tijdschrift voor Economische en Sociale Geografie 90(4): 363-378.

Sass, S. (2006). The Development of Employer Retirement Income Plans. Oxford Handbook of Pensions and Retirement Income. G. L. Clark, A. Munnell and M. 
Orszag. Oxford, Oxford University Press.

Schoenberger, E. J. (1997). The cultural crisis of the firm. Cambridge, Mass. ; Oxford, Blackwell.

Schulz, M. (2004). "Changing the Rules of the Game: The Reform of Corporate Governance in Japan." The Japanese Economy 32(1): 87-131.

Seike, A. (1997). New trends in Japan's labor market : changes in employment practices. Tokyo, Japan, Foreign Press Center/Japan.

Sheppard, E. (2001). "Quantitative geography: representations, practices, and possibilities." Environment and Planning D-Society \& Space 19(5): 535-554.

Soskice, D. W. (1990). "Wage determination: the changing role of institutions in advanced industrial economies." Oxford Review of Economic Policy 6: 36-61.

Storper, M. (1987). "The post-enlightenment challenge to Marxist urban studies." Environment \& Planning D: Society and Space 5: 418-426.

Storper, M. (1997). The regional world : territorial development in a global economy. New York ; London, Guilford Press.

Strauss, A. L. and J. M. Corbin (1998). Basics of qualitative research : techniques and procedures for developing grounded theory. Thousand Oaks ; London, Sage.

Suto, M. and M. Toshino (2005). "Behavioural biases of Japanese Institutional Investors: fund management and corporate governance." Corporate Governance-an International Review 13(4): 466-477.

Taylor, M. (1984). "Industrial-Geography." Progress in Human Geography 8(2): 263-274.

Thatcher, M. (2004). "Varieties of capitalism in an internationalized world - Domestic institutional change in European telecommunications." Comparative Political Studies 37(7): 751-780.

Useem, M. (1995). Reaching Corporate Executives. Studying Elites Using Qualitative Methods. R. Hertz and J. B. Imber. London and New Delhi, Sage: 18-39.

Usuki, M. (2007). "Assessing Private Pension Plan Regulation in Japan." NLI Research Institute.

Weber, E. U., A. R. Blais, et al. (2002). "A domain-specific risk-attitude scale: Measuring risk perceptions and risk behaviors." Journal of Behavioral Decision Making 15(4): 263-+.

Whiteford, P. and E. Whitehouse (2006). "Pension challenges and pension reforms in OECD countries." Oxford Review of Economic Policy 22(1): 78-94.

Yeung, H. W. C. (1998). "Capital, state and space: contesting the borderless world." Transactions of the Institute of British Geographers 23(3): 291-309.

Yeung, H. W. C. (2000). "The dynamics of Asian business systems in a globalizing era." Review of International Political Economy 7(3): 399-433.

Zingales, L. (2000). "In search of new foundations." Journal of Finance 55(4): 16231653. 


\section{APPENDIX:}

TABLE 1:

\begin{tabular}{|l|r|r|r|}
\hline Table 1: The relationship between agreement/disagreement and country \\
\hline Chart / & Cramer's V (in & $\begin{array}{r}\text { Number of } \\
\text { Question }\end{array}$ & $\begin{array}{r}\text { Cramervations } \\
\text { absolute value) }\end{array}$ \\
\hline 1 & $12.0148(0.001)$ & 0.0851 & 1,658 \\
2 & $1.9938(0.158)$ & 0.0359 & 1,546 \\
3 & $6.2094(0.013)$ & 0.0668 & 1,392 \\
4 & $6.1415(0.013)$ & 0.0645 & 1,477 \\
5 & $40.8860(0.000)$ & 0.1594 & 1,610 \\
6 & $3.9248(0.048)$ & 0.0512 & 1,500 \\
7 & $77.2981(0.000)$ & 0.2142 & 1,684 \\
8 & $33.9738(0.000)$ & 0.1483 & 1,545 \\
9 & $0.0190(0.890)$ & 0.0035 & 1,555 \\
10 & $0.0036(0.952)$ & 0.0016 & 1,504 \\
11 & $3.6283(0.057)$ & 0.0498 & 1,465 \\
\hline
\end{tabular}

Notes: Question responses are aggregated into two categories only (agree and disagree).

a) One degree of freedom.

b) No. of observations for Japan and US combined. For simplicity of interpretation, neutral responses are not included, so the total number of observations changes across questions.

\section{CHARTS:}

1) I would characterize DB pension deals as long-term contractual remuneration agreements for employees' services and / or support

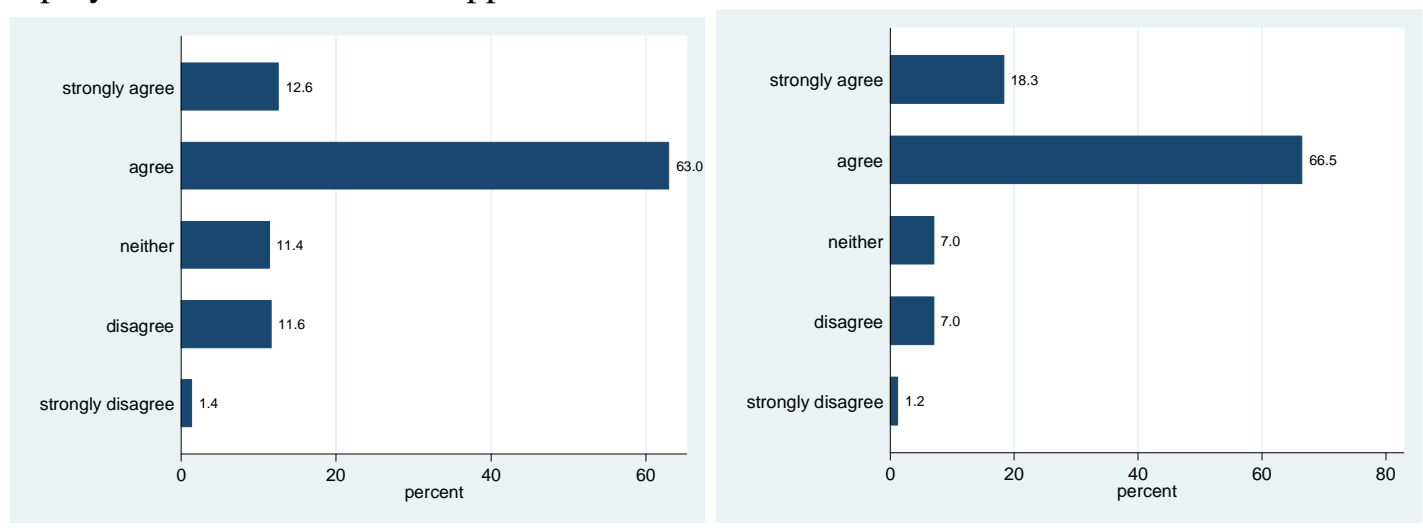


2) The most forceful advocates for DB pensions are older workers nearing retirement.

Japan

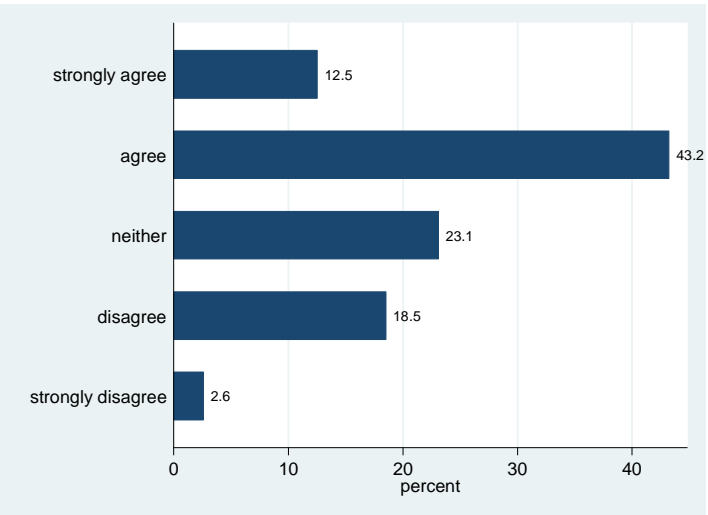

USA

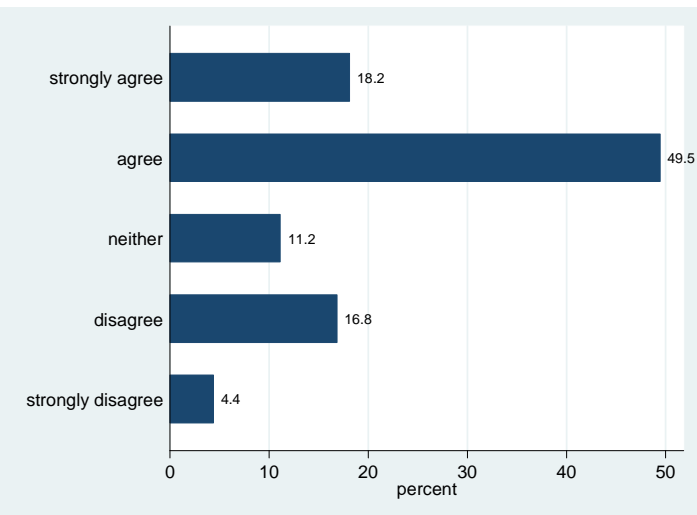

3) The DB pension was originally an implicit 'promise' that was changed by regulatory intervention into an explicit contractual 'guarantee'.

\section{Japan}

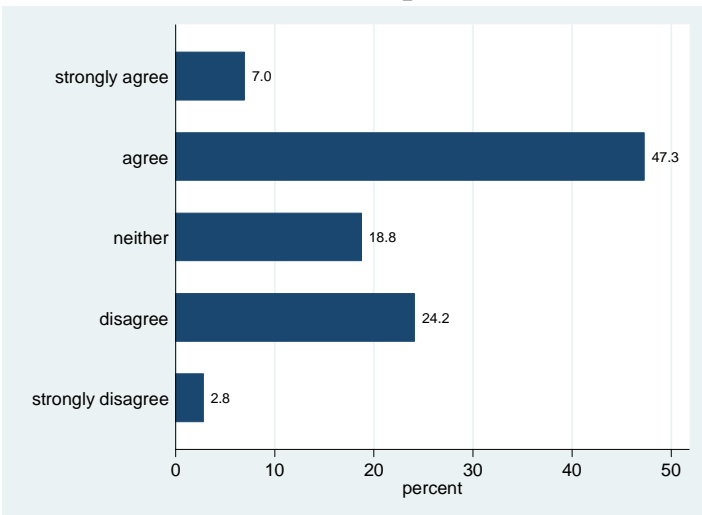

USA

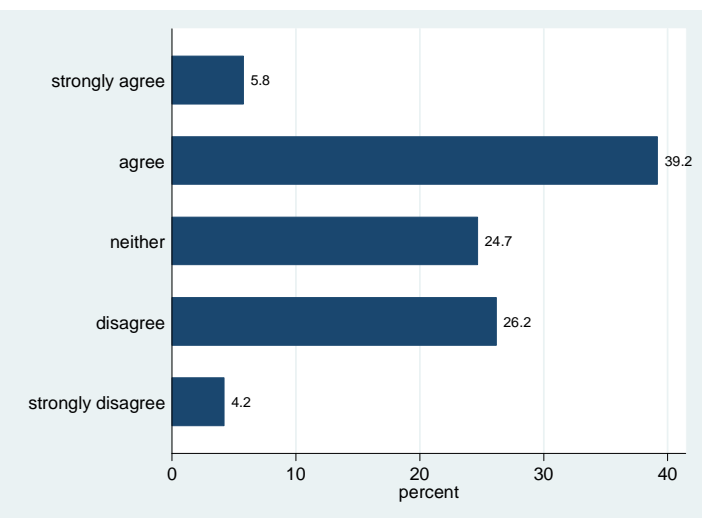

4) I would characterize DB regulations and governance as becoming overly restrictive.

Japan

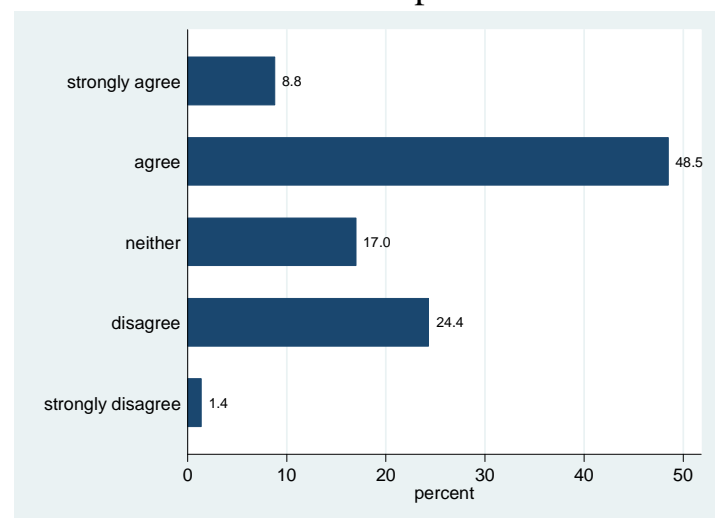

USA

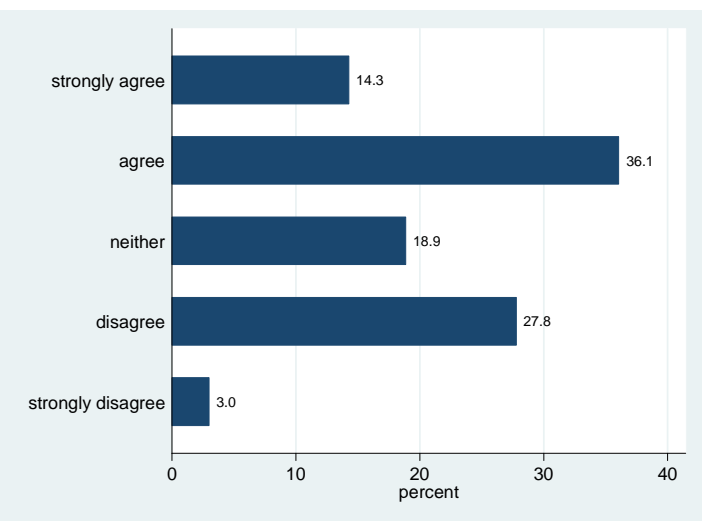


5) DB pensions were built incrementally over the course of 50 years; the escalation of commitments resulted in a large unexpected burden for sponsoring firms.
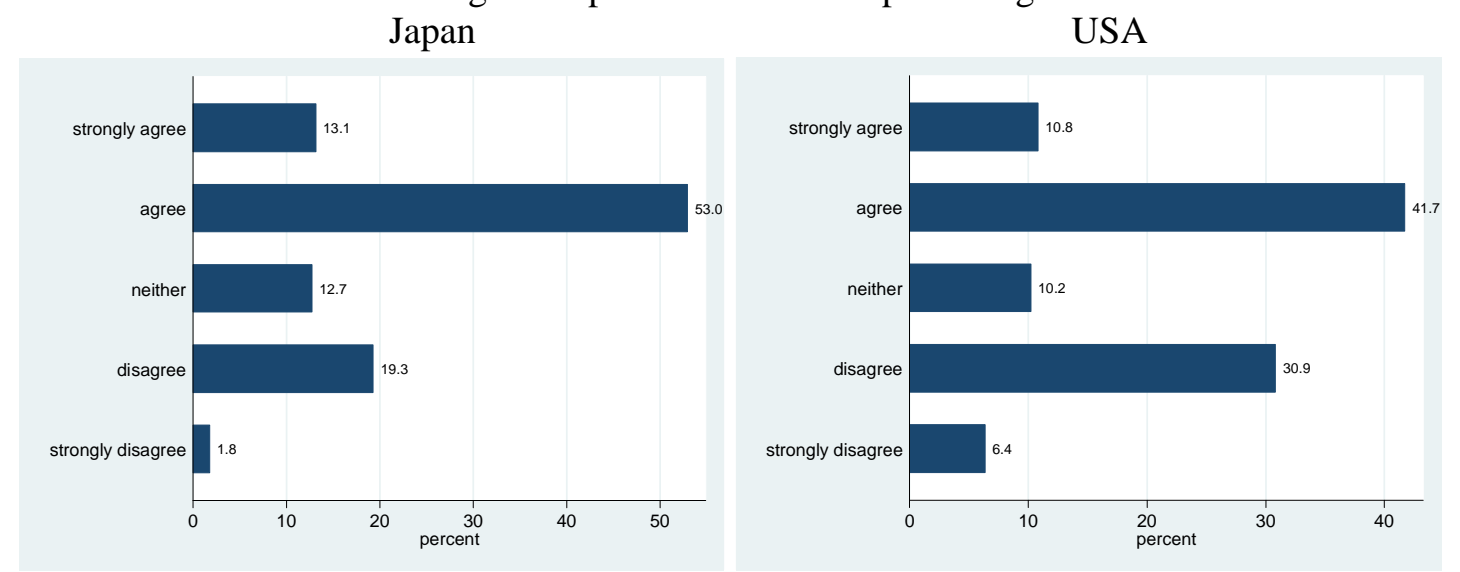

6) Any organizational component that hinders a firm's flexibility with respect to resource allocation and production decisions would put the firm at a disadvantage.
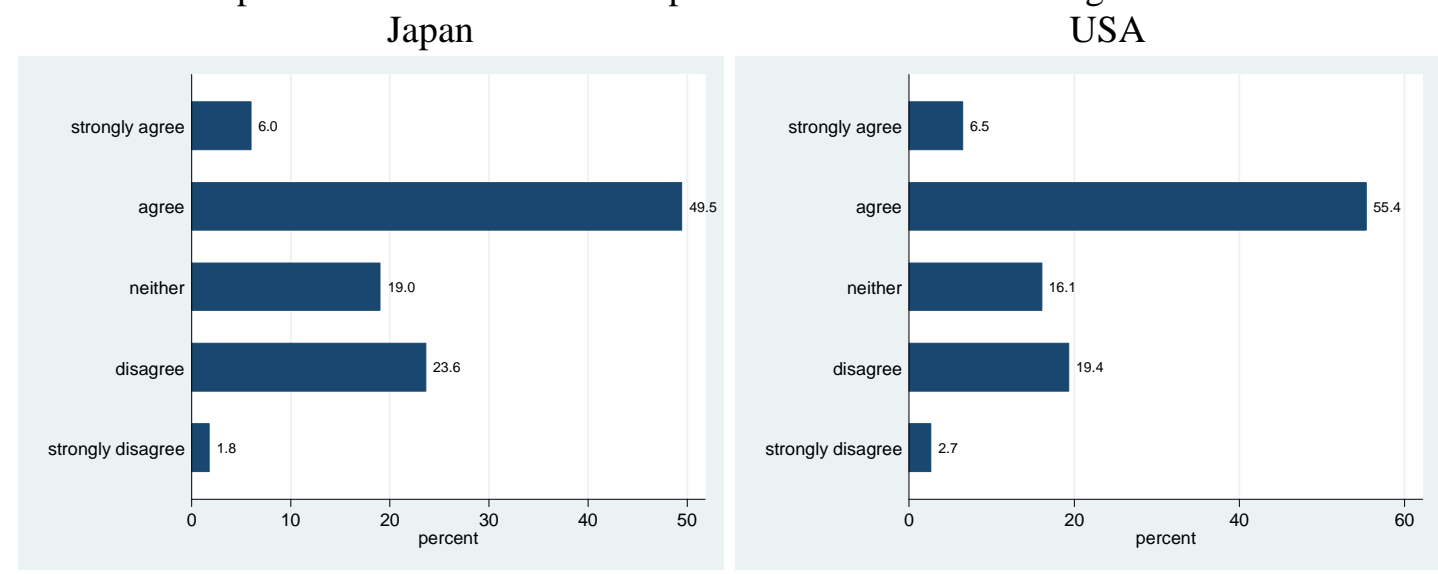

7) Plan sponsors cannot take into consideration all unforeseen contingencies stemming from longterm DB risks.
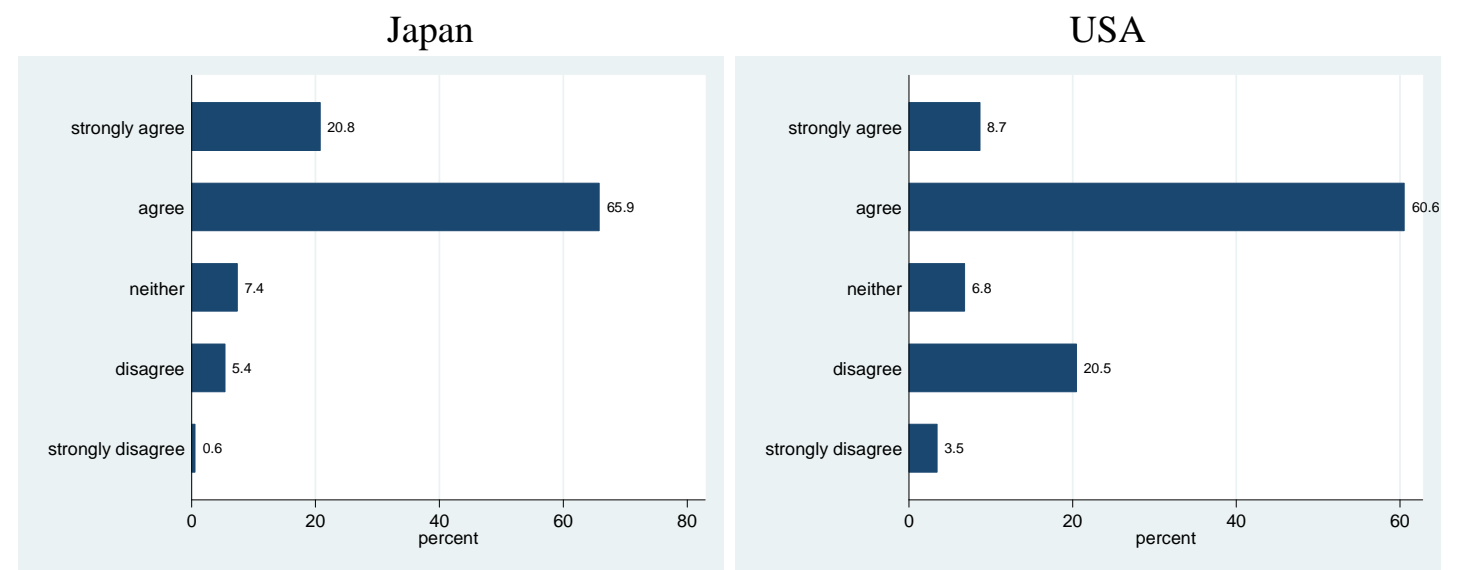
8) Increased market competition stemming from deregulation and globalization has weakened the competitive position of private DB plan sponsors with large pension liabilities.
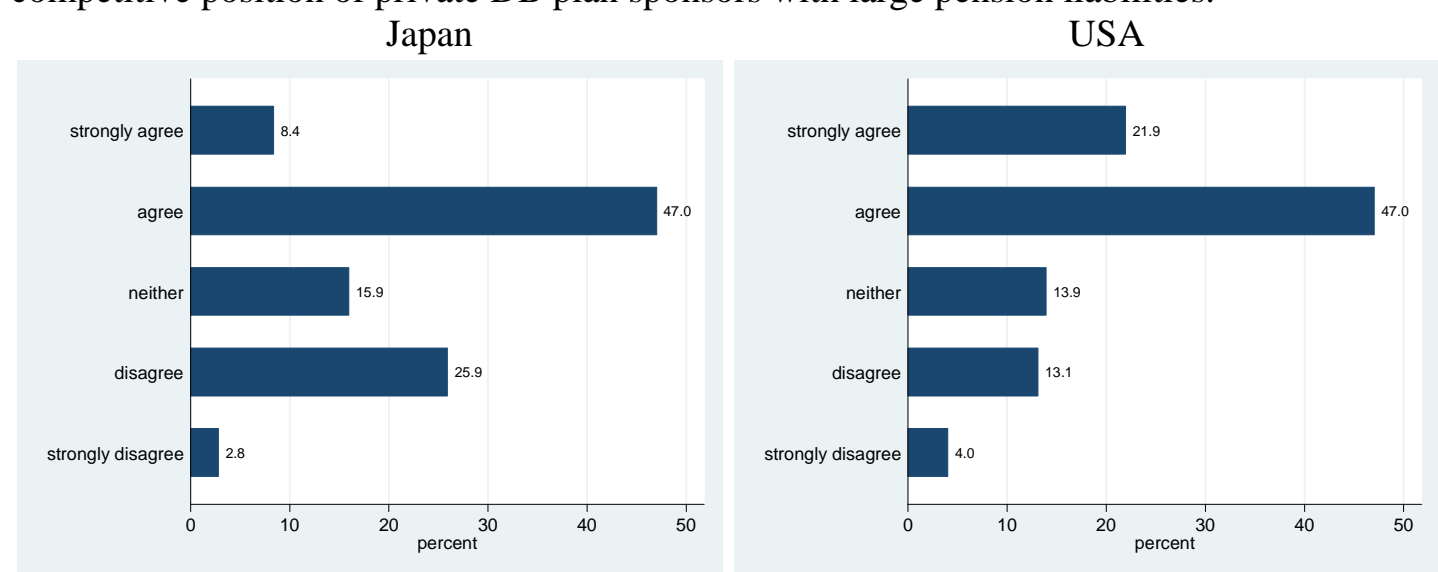

9) The embedded nature of the DB pension system presents significant resistance to restructuring.
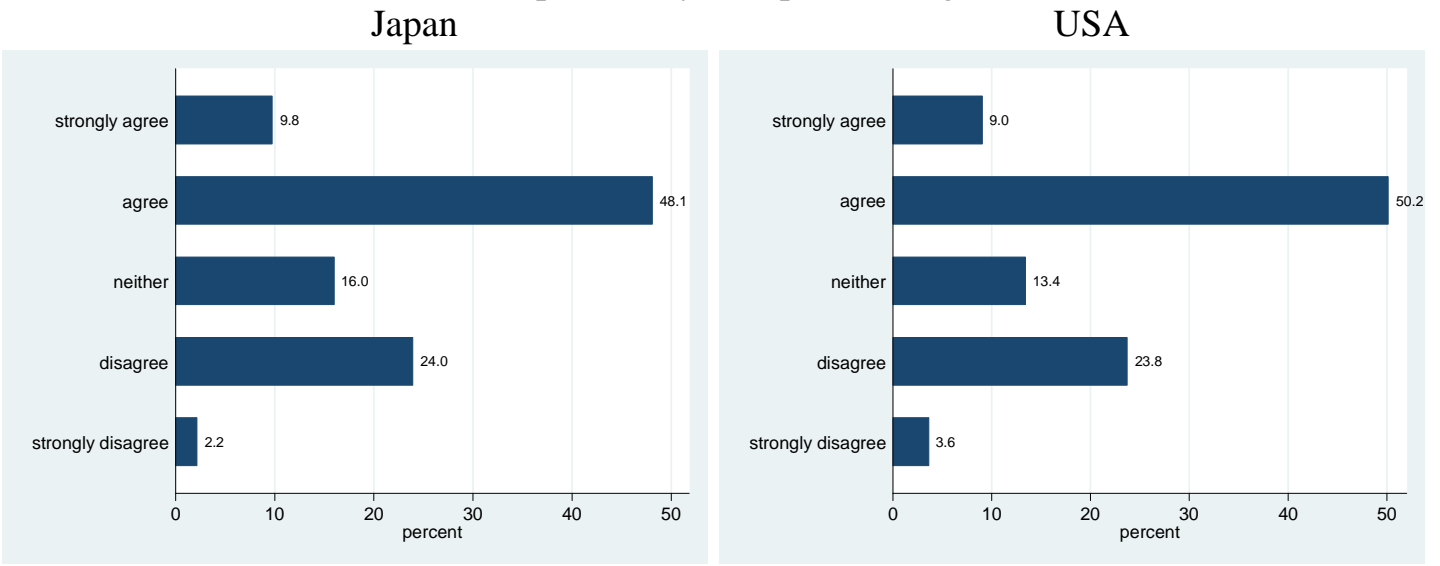

10) Asset allocation policy is difficult to determine in DB plans because of the competing trustees' interest in benefit security and plan sponsors' interest in cost containment.
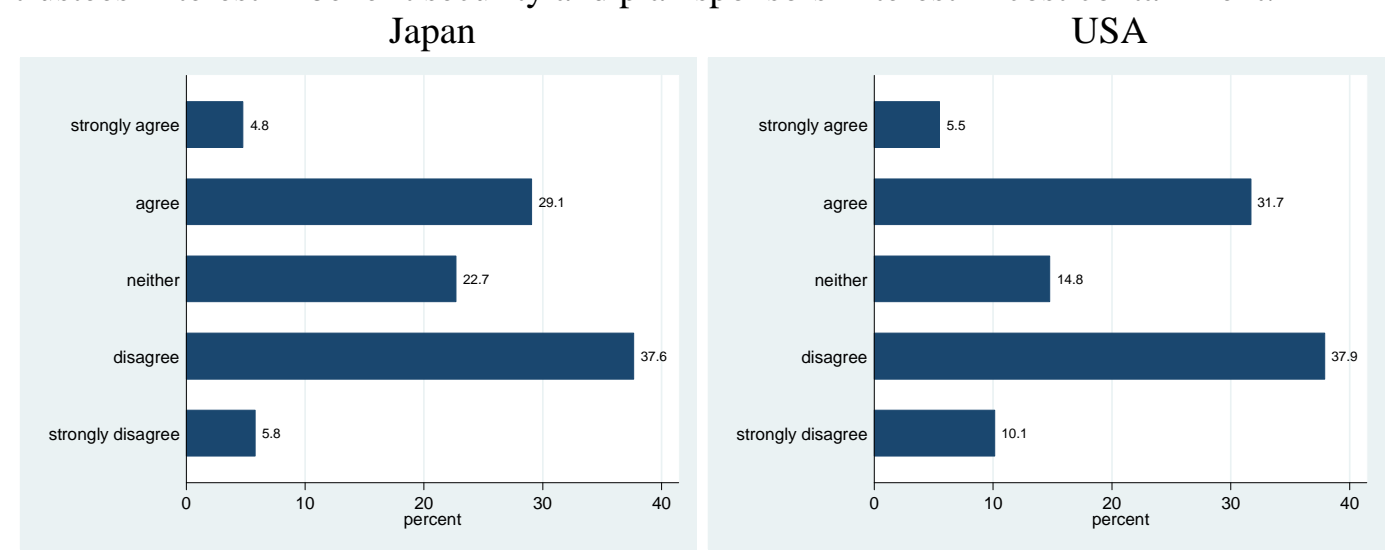
11) Intergenerational deals, of the type made by firms agreeing to pay DB pensions, generate unknown and often negative effects for future generations who are expected to manage the burden of the liability (legacy).
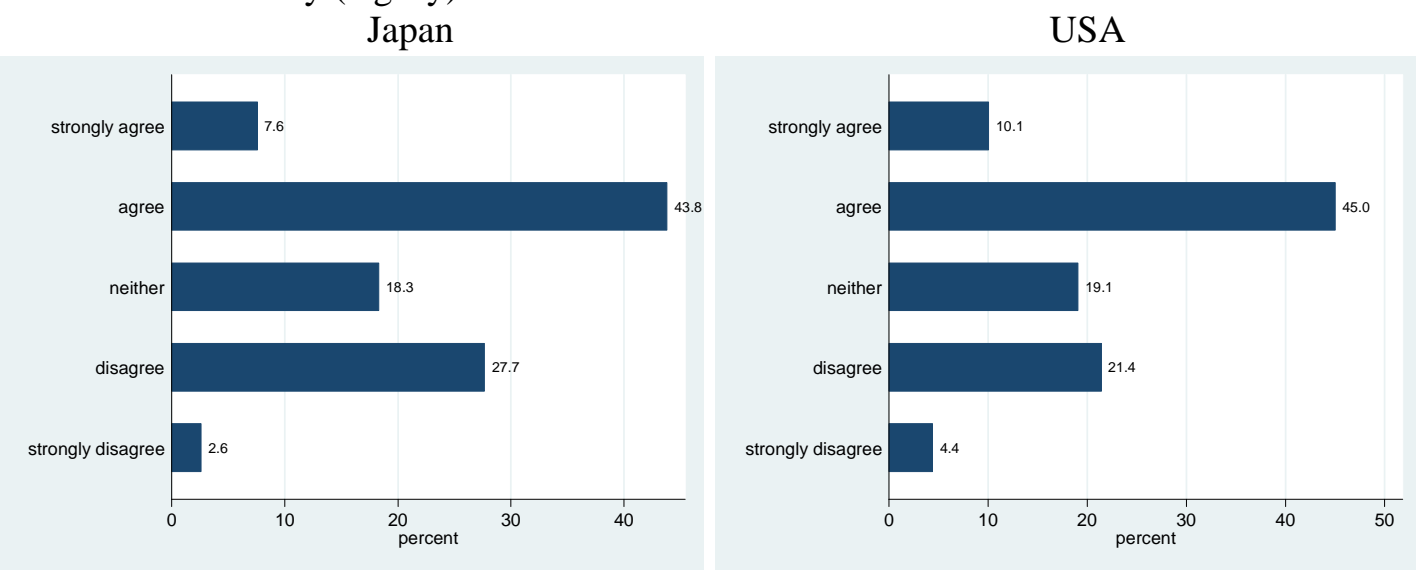